\title{
Insolvent Local Government: German Approaches to Prevention*
}

\author{
UDK: $352: 336.1$
}

Thomas Duve

Working Group for Economic Administration -

AWV (registered association), Eschborn, Germany

tduve@web.de

Wolfgang Drechsler

Tallinn University of Technology, Tallinn, Estonia

wolfgang.drechsler@ttu.ee

\section{ABSTRACT}

The global financial crisis is affecting local governments particularly strongly. The threat of insolvency looms large for many local governments, and therefore, it is unfortunately very timely to examine this issue. Can genuine bankruptcy occur, should it be allowed to occur, can it be prevented, and if it cannot be, how can it be managed well? In order to do so, the current essay sets out to investigate, on an empirical basis, how Germany has so far (i.e., before the crash) dealt with the issue of municipal insolvency. This pre-crisis approach also underlines the importance of the topic, because it shows that even in more or less financially solid times, municipalities were already exposed to high financial pressure. Now, the crisis has increased the number of municipalities facing a budget crisis. The results of the present investigation can assist in dealing with the consequences of the crisis. On account of its high and indeed paradigm-setting level of municipal autonomy, the possibility of drawing lessons from Germany should be particularly interesting.

Key words: local government, local finances, financial crisis, municipal insolvency, prevention

$J E L: R 51$

* The research this article is based on was partly funded by the Estonian Science Foundation (Project No. 7577).

Duve, T. \& Drechler, W. (2011). Insolvent Local Government: 


\section{Introduction}

The current global crisis and/or its aftermath are affecting local governments in most European - and other "Western" - countries through a specific impact, not least of which because of the general and "timehonoured" tendency of national and regional governance bodies to "hand down" financial obligations to the municipal level (Schwarting, 2008, p. 268; Faber, 2005, p. 945). This problem is exacerbated by two current phenomena: On the one hand, the increase of the importance of the local life-world for citizens in a globalised and, where applicable, European environment (see Stern, 1996, esp. 43; also Isin, 2002 and Drechsler, 1999), which makes more and not less financial resources necessary, and, on the other hand, the recent ideological tendency in public administration (PA), associated with the concept of the New Public Management (NPM), to dismantle local autonomy in the name of efficiency and - simply assumed - economies of scale, in other words a bias in favour of larger and more centralised units and against anything local and municipal (e.g., Seitz, 2008).

Although the latter perspective has more or less vanished on the academic and scholarly level, at least in Europe, with the rise of the concept of the Neo-Weberian State (NWS) as the post-NPM paradigm (see Pollitt et al., 2009), it is still alive and well in policy and particularly on the municipal level (Cf. Reichwein, 2007). It is true that NWS is arguably the logical PA paradigm for getting out of the crisis. In its rhetoric and general assumption, NPM is very much "pre-crash" and is indeed part of the way of thinking that has led to, or at least significantly contributed to, the crash coming about as harshly as it did (see Drechsler, 2009c). One reaction by financially troubled countries has been to force savings, cuts and such NPM measures that "reduce the state" (see Peters et al., 2010) - not without causing particularly harsh effects at the local level.

All of this makes the issue of local governments becoming insolvent a particularly interesting topic. Can this occur, should it be allowed to occur, can it be prevented, and if it cannot be, how can it be managed well? It seems that this is an issue not least of which for Central and Eastern Europe, where Local Self-Government is arguably under particular duress and thus on the defence due to the crisis and partially even before it. To approach this question, it is especially interesting to look at the 
Federal Republic of Germany for a variety of reasons. Although several federal investment programmes (see Zukunftsinvestitionsgesetz, 2009) seem to have had a positive effect on many municipalities in the sense that the crisis has not hit them as hard as had been feared (OECD, 2010), Germany has been particularly affected by the crisis (BMF, 2009), and there are and will be particularly detrimental effects for the local governments (Käppner 2009; see most recently Oberhessische Presse, 2010).

On the one hand, Germany is generally a country with a classically very strong local sector and, certainly in its self-understanding, is the cradle of municipal autonomy (and for municipal autonomy the cradle of democracy; see Drechsler, 2001). Its founding father and "patron saint", Karl vom Stein, recently celebrated his $250^{\text {th }}$ birthday (see Drechsler, 2007; Duchhardt, 2007, esp. 199-203; Ritter, 1981, esp. 196-199) and the first establishment act of Municipal Autonomy, the Preußische Städteordnung, celebrated its bicentennial (see Drechsler, 2008; Ordnung für sämmtliche Städte, 1957). This idea also had a significant impact on the restoration of Local Self-Government in Central and Eastern Europe after 1989 (Drechsler 2008, p. 137).

On the other hand, especially at the local level, NPM - under the name "New Steering Model" - has hit especially hard - often through good intentions - and been promoted with verve by the "think-tank" of the municipalities themselves (the "KGSt"), the Federal Ministry of the Interior, a very powerful foundation (Bertelsmann) and many academics and civil servants. This created an atmosphere in which to diverge from the assumptions of NPM, even to demand calculations, costs or justifications, was regarded as heresy (Drechsler, 2009a, pp. 315-319). Regarding Municipal Autonomy, NPM also united with the "social engineering" approach of the 1970s and its cult of the doable (on the history of the approach, Etzemüller, 2009), and Germany had become one of the countries where it was just assumed that larger municipal units would lead to increased efficiency. The otherwise very important "Rastede" decision of the Bundesverfassungsgericht, for instance, proclaimed this very view en passant, ${ }^{1}$ never mind that we have no reason whatsoever to believe that

1 BverfGE 79, 127; »In many respects, however, a centralistically organised administration could work more rationally and cheaply, "153. Regarding the positive aspects of Rastede, see Schmidt-Aßmann, 1991. 
increased municipal unit size automatically increases efficiency, but we do know that there is a tendency for it to weaken democracy and citizen identification with the community (Drechsler, 1999).

In this context, the current essay sets out to investigate, on an empirical basis, how Germany has so far (i.e. before the crash) dealt with the issue of municipal insolvency. Specific approaches to resolve the current financial crisis and to prevent future local financial crises are at the centre of these observations. To look at those pre-crash tools may be of particular interest, because they were formulated and tried without the hastiness and confusion that might have accompanied any crisis-based attempts at solutions. Also, there is enough empirical material and analysis for them to already render such an investigation possible.

As the purpose of this essay is to familiarise the non-expert regarding Germany, we have utilised German-language literature (which completely dominates this specific discourse anyway, of course) as much as possible to show how the issue is discussed nationally. The empirical parts, and to a large extent also the argumentation of this essay, are based on Duve, 2008a, Duve, 2008b and Duve, 2009b, which were also part of Duve, 2009a. All were in German.

\section{Extreme indebtedness as a danger to local autonomy}

The debt situation of the municipalities had already deteriorated significantly in the years before the global financial and economic crisis. This development was expressed in the fact that more and more municipalities could not balance their budget (Henneke, 2008a, p. 232). The rapid increase in Kassenverstärkungskredite (cash advances) confirms this trend impressively.

The financial crisis worsened, often greatly, the budget-deficit situation of many municipalities (Bock, Hein and Weinberger, 2010). Due to a substantial decrease of income deriving from the Gewerbestever (trade or business tax) - their main source of income - and a sharp increase of social expenditures, the municipalities were already carrying a deficit of $€ 7.1$ billion in 2009 (Statistisches Bundesamt, 2010a). In addition to that, a number of German municipalities had to carry risks caused by Cross-Border-Leasing contracts. The financial problems and failures of many American banks and insurances (Kirbach, 2009) now 
threaten the municipalities involved. Until today, the feared problems were held off, however, or at least did not emerge.

Generally, municipal life is suffering from a high indebtedness, and in its present form, it is not sustainable if too high a percentage of the revenues has to be spent on paying back loans. The municipalities then often lack money for necessary investments, which consequently has detrimental effects on public infrastructure. Also, and maybe even especially so, the decline of voluntary tasks (i.e., measures which local governments may take but are not required by law), which many municipalities can no longer afford, harm the social and cultural life within the municipalities (Henneke, 2008a, p. 232; Welt, 2010, p. 10), although it is those things that make life in a specific community especially attractive and satisfying.

This is particularly worrisome if one considers the key role municipalities play within the German state system, which becomes evident when one examines their functions and tasks. Municipalities implement approximately 80 per cent of all state laws and thus form the basis of the state administration (Knemeyer, 1997, p. 204). Via their investments (e.g., in cultural and social institutions as well as in the municipal infrastructure), they also contribute significantly to the prosperity of the population (Raske, 1971, pp. 172-173). Connected to this is the importance of local governments as carriers of general services for the public (Forsthoff, 1958).

In Germany, it is generally the Länder (roughly, the states) that deal with the local governments, not the federal level authorities (see Table 1).

\section{Table 1: Arrangement of the administrative levels in Germany}

\begin{tabular}{|l|l|}
\hline $1^{\text {st }}$ State Level & 1 Federation \\
\hline $2^{\text {nd }}$ State Level & 16 Länder (of it 3 City states) \\
\hline $1^{\text {st }}$ Local Level & 323 Counties and 112 independent Cities \\
\hline $2^{\text {nd }}$ Local Level & 12,188 dependent Municipalities (within Counties) \\
\hline
\end{tabular}

Source: Statistisches Bundesamt, Fachserie 14, Reihe 3.3, 2007.

The constitutional tie of the municipalities to the Länder is connected with a right of supervision by the latter (Wagener and Blümel, 1997, p. 114). Federal supervision over the municipalities does not exist in Germany (Gern, 2003, p. 520). This essay therefore deals with 
the question of how the Länder attempt to deal with their responsibility for the indebtedness of the municipalities. The focus is in particular on the way the supervising authorities act in handling local budgetary hardships.

A look at the indebtedness of the German state shows that in relation to the total sum, $€ 1.7$ trillion in 2009, the indebtedness of the municipalities amounts only to about 7 per cent (Statistisches Bundesamt, 2010b).

This small percentage carried by the local level, however, is no reason for carelessness, since it is not distributed equally among all municipalities. A closer look at local indebtedness shows considerable regional and structural variations (Junkernheinrich and Micosatt, 2008, p. 14). The very high indebtedness is challenging to some Länder and especially to their supervisory authorities, which also bears on their capacity to intervene. Thus, the interventions covered by the supervisory authority varies strongly according to region and financial situation.

The task of the supervisory authority is limited to monitoring the legality of the actions of the local administrations (see Art. $49 \S 32^{\text {nd }}$ stc of the Constitution of Rhineland-Palatinate). For the enforcement of this mission, there are various measures available. Repressive measures are specified comprehensively in the Gemeindeordnungen (laws covering affairs of local government) of the Länder and are implemented only according to the principle of appropriateness. They consist of the following actions:

- $\quad$ Right to Instruct

- Right to Object and to Abolish (if there are preceding violations of law)

- Right to Command (when legal obligations are not fulfilled)

- Ersatzvornahme (exercising an action by the supervisory authority at the expense and in the name of the municipality)

- Appointment of a commissioner (if the measures listed above are insufficient)

12 Uprava, letnik IX, 2/2011 
- Dissolution of the local council ${ }^{2}$ and pre-term ending of the Mayor's mandate ${ }^{3}$ (only possible in some Länder)

The options for interventions of the supervisory authority of the Länder into matters of local autonomy are thus clearly defined. Beyond these measures, no further legal actions exist.

\section{Autonomous action and national specifications - which scope do German municipalities have?}

According to Art. $28 \S 2$ GG ("Grundgesetz"), the German Constitution guarantees to the municipalities the right to regulate all affairs of the local community by themselves. However, there are a substantial number of national specifications that limit the extent of autonomy and responsibility. Next to voluntary self-administration tasks, which were mentioned supra, there are also many duties assigned by the Länder. The municipal execution of all tasks stands under law proviso (Falk, 2006, p. 117).

Mainly because of the duty to execute state tasks, over the years, the interconnectedness between the municipal level and that of the Länder has increased substantially (Burgi, 2006, p. 88). While voluntary tasks are at the core of the self-government guarantee, in terms of percentage, the assigned government tasks prevail. In the majority of municipalities, voluntary tasks represent less than 10 per cent of expenditures (Schwarting, 2005, p. 142). However, when transferring state duties to the local level, appropriate funding by the Länder plays a central role. In the past, the Länder did not often act accordingly, and in fact, this is one of the reasons for the current financial crisis of many municipalities (Schwarting, 2008, p. 268; Albers, 2005, p. 61; Faber, 2005, p. 945; Frischmuth, 2008, p. 136). How to determine, on an empirical basis, the financial volume required for a municipality remains an unsolved problem (Junkernheinrich, 2007, p. 173).

In order for the municipalities to be in a position to carry out their tasks appropriately - also to ensure equal life conditions as stipulated by Art. $72 \S 2$ GG - they receive money from the Länder within the scope of

$2 \S 141$ a GemO Hessen; § 84 Kommunalverfassung Mecklenburg-Vorpommern; § 125 GemO Nordrhein-Westfalen; § 125 GemO Rheinland-Pfalz.; § 122 Abs. 2 GemO Thüringen.

$3 \S 118 \mathrm{GemO}$ Sachsen.

Uprava, letnik IX, 2/2011 
the municipal revenue-sharing depending on funding requirements. In other words, richer municipalities get less money than poorer ones. The subsidiary character of these allocations has been gone for a long time; in many places, they are now a key source of revenue. In the East German Länder, the share of these allocations relative to the municipalities' total receipts is roughly 50 per cent (Lenk and Rudolph, 2005, p. 57). Thus, municipalities are very dependent on the Länder, especially as the amount of the transfers are not fixed but depend on the economic situation of the respective Länder. Another problem arises as a result of the still increasing financial losses of many Länder, which also has an impact on the funding of the municipalities (Henneke, 2008b, p. 858). Particularly in the current crisis that also burdened the budgets of the Länder, cuts in state allocations have catastrophic effects on the budget situation and thus on the local autonomy of the municipalities (Bock, Hein \& Weinberger 2010).

Mainly due to the global financial crisis, the German federal government created a municipal finance commission in 2010 (BMF, 2010). Its task is to sort out municipal finance, and its tasks include finding a substitute for the commercial tax as a source of revenue. It remains to be seen how successful the work of the commission will be, especially as it will not tackle the key topic of restructuring the spending structures. Without a doubt, the essential first step towards a sustainable prevention of municipal insolvency in Germany would be the appropriate matching of municipal spending with the genuine revenue situation.

\section{Insolvency proceedings as a sword of Damocles for municipalities?}

The financial crisis brought the topic of insolvency to the agenda once again, but mainly related to an international insolvency law for countries (IWD, 2010, p. 6). The current legal situation in Germany does not include the concept of municipal bankruptcy. $\S 12$ (1), no. 2, of the "Insolvenzordnung" (InsO) declares that bankruptcy proceedings against the assets of legal entities under public law are inadmissible unless the law of the Länder states otherwise. None of the German Länder have stated so (Faber, 2005, p. 938).

14 Uprava, letnik IX, 2/2011 
The German municipalities, like the German state as a whole, are considered to be credit-worthy without restrictions. ${ }^{4}$ Consequently, municipalities receive credits from banks even when they have already reached a very high level of indebtedness. This, in turn, means that municipalities in Germany can never go bankrupt in the sense of bankruptcy as the state in which one cannot receive credit anymore to honour one's obligations. For the Länder, this has the consequence that they never have to stand in for the municipalities' commitments (Engelsing, 1999).

\subsection{Arguments for municipal insolvency proceedings}

Thus, to at least consider municipal insolvency proceedings seems logical, especially in the current context. The advantage of such proceedings, it has been argued, would be that with the introduction of insolvency proceedings, limits to local indebtedness would no longer be achieved only via legal regulations but also via market mechanisms (incentive effect) (Blankart, Fasten \& Klaiber, 2006, p. 571) - although this of course assumes the possibility of market effects in the public sphere. More importantly, it is intended to give municipalities with extremely high debt the chance to start over by using an insolvency proceeding, in other words by declaring bankruptcy (redevelopment effect) (Paulus, 2003, p. 869).

As a direct consequence of the possibility of a municipality's insolvency proceedings, the banks would have to take into account the risk of losing a certain amount of the granted credits, which means that the existing zero-risk for credits could not be maintained - in fact, this is the idea. The potential risk would then be determined by the banks on the basis of ratings (Interview Bergmann, 2008). Depending on the solvency of the municipality, the credit costs could thus increase and the credit conditions for the municipality could worsen.

According to the expectations of the supporters of the possibility of municipal insolvency, politicians would endeavour in the future to reduce indebtedness or at least to keep it low in order to avoid high credit costs or even insolvency proceedings. Thus, cases of insolvency would not actually be expected to occur, but the possibility of it would serve as

4 In accordance with the "Solvabilitätsverordnung", local credits have a risk weighting after the credit risk standard of 0 percent. 
a means of deterrence (Meyer, 2007). Creditors and debtors alike would therefore do everything to avert bankruptcy (Blankart, 2007).

If a municipality, however, is already trapped in the vicious circle of inescapable debt, a modified insolvency procedure would work as an instrument for reorganisation (Paulus, 2003, p. 872), providing the municipality with the possibility of a fresh start. Moreover, with the help of this procedure, the possibility of reducing personnel faster is seen as an additional benefit aiding in preventing future burdens (Borchert, 2004, p. 3; Frielinghaus, 2008, p. 997).

\subsection{Arguments against municipal insolvency proceedings}

The described expectations certainly seem to be attractive at first sight. At second glance, however, several problems become apparent.

To achieve the described incentive effect with the help of variable credit conditions, the Länder would in principle have to rule out rescuing municipalities from financial difficulties (a so-called bailout). Otherwise, the banks would not be able to realistically estimate the credit risks. The question, however, is how to distinguish between state grants and a bailout? The grants of the Länder to many municipalities are not negligible. Rather, as has already been mentioned, this allocation is an essential part of the revenues. Without this money, a recovery of the budgetary situation would be impossible for many municipalities. It cannot be denied that these allocations already represent a sort of bailout (Schwarting, 2005, p. 145).

Furthermore, if municipalities are to be sanctioned via insolvency, they must be able to influence their financial situation. The municipalities have this kind of freedom only to a very limited extent, since they have been assigned many tasks and are thus tied to legal requirements to a large extent. Unlike private companies, which can, for example, limit their production, order short-time work, reduce personnel quickly or even relocate their headquarters' location, municipalities do not have these possibilities at their disposal.

On the revenue side, also, the range of possible actions is rather limited. In particular, financially weak municipalities are to a very large extent dependent on regular grants by the Länder. These financially weak municipalities with few options for action are most likely to be affected by insolvency (Interview Wohltmann, 2008). Local authorities can hardly 
change this situation, because municipal legislation and municipal financial resources are an area of competence of the Länder (WernerJensen, 2006, p. 32) and thus out of the control of the municipalities (Klein, 2005, p. 72).

Were an insolvency case in fact to occur, then the central question would emerge regarding which municipal assets could be ordered to be sold by the liquidator, since those assets are directly linked either to voluntary tasks or to state-tranferred duties - and a clear distinction between those is often difficult to make (Albers, 2006, p. 756). If the insolvency proceedings restricted voluntary tasks, this could eliminate the field of self-responsible performance of the municipalities and thus liquidate local self-government in the affected municipalities (Faber, 2005, p. 945).

Another problem is that in most cases, an intensive budgetconsolidation process would already have taken place, in the course of which the sale of most of the possible assets would have been taken into consideration. Thus, insolvency would not come at a time of large variety of possible actions. On the contrary, the debt level would be extremely high, and most of the assets would have been sold already. There would not be much left for the insolvency proceeding. In addition, in recent years, municipalities have outsourced their assets very much and, through that, partly also their debts. The proportion of this "outsourced debt" in, for example, limited-liability companies amounted to 53.1 per cent at the end of 2007 (Junkernheinrich and Micosatt, 2008, p. 16).

It is interesting to note that in the German discourse, the discussion of the possibility of municipal insolvency proceedings is exclusively an academic one (i.e., it has taken place only among scholars and within academic articles). The responsible Ministries of the Interior of the Länder and the municipal associations decline to even discuss this option. As reasons, the above-mentioned arguments are usually cited, being perceived to much outweigh any advantages. ${ }^{5}$ Whether they are the reason or just the excuse is another matter of course. We may assume an amalgam of both. It is probably fair to say that the possibility of municipal bankruptcy is so alien to the German legal-administrative system and culture that it is indeed not an option, not even after the changes

5 Interviews with Wohltmann; Dedy; Frischmuth; Mnich; Kirchmer; Dornig; Puhr; Stöfen; Penzenstadler-Hennig; Würger, Hoerenz; Wagenführer. 
in thinking that NPM has actually brought about. Quite apart from whether such an instrument would actually be a good idea - and as, indeed, context-wise, it probably is not, already for this reason - it is certainly an unrealistic one. If all policy-actor sides involved (i.e., specifically the Länder and municipalities and their associations) agree that it would be a bad idea and if there is insufficient pressure to push them (which surely is the case; there are no prominent champions of it in either the media or politics and lobbying, and the topic is not exactly one to excite the general public on its own), then realistically, the idea is doomed.

The general need for problem-solving nevertheless remains. Thus, the question presents itself of how a quasi-insolvent municipality can be reorganised without local insolvency proceedings on the one hand and how the way into the debt trap can generally be avoided on the other.

\section{The state takes over local administration: the implementation of a state-appointed commissioner using the example of the city of Bad Münster am Stein-Ebernburg}

If budgetary deficits cannot be fixed by comparatively mild actions within the realm of municipal control, or if measures of this sort are not deemed useful, by law, the respective Länder can appoint a commissioner. Such appointments are in fact only made very rarely. This does not mean, however, that cases of budgetary hardship are also that rare - to the contrary! Frequently, however, the budgetary problems are so extensive that the use of state commissioners is prevented either by the Länder themselves - if they do not regard it as an appropriate measure to solve the financial problems of the respective municipalities - or by political obstacles (party affiliations for instance).

As a matter of fact, however, the only concrete case in which a state commissioner was appointed is that of the city of Bad Münster am SteinEbernburg (BME). ${ }^{6}$ While this is of course as narrow an empirical basis as there possibly can be, here we do have a real-life, practical example

\footnotetext{
6 The city of Bad Münster am Stein-Ebernburg (3,792 inhabitants) in Rhineland-Palatinate is situated to the south-west of Mainz in the administrative district of Bad Kreuznach and is one of ten municipalities that make up a larger consociation of municipalities, also named Bad Münster am Stein-Ebernburg. For more information on the city, see www.vg-bme.de/ (Accessed on 15 September 2010).
} 
of this institution and looking at it more closely can reveal several problems that may have an impact on its potential success (see Duve, 2008b).

The main reason for BME's deficit was its health-spa business, which was run by the town itself. This business caused immense losses over a long period, which had to be covered by the town. The situation deteriorated more and more since the late 1980s, when the number of customers decreased significantly, and this trend persisted throughout the 1990s, not least of which because of an increase in competition from other spa resorts and as a result of federal health-care reforms (Interview Schoon, 2007).

Already in the 1980s, the supervisory authority realised that trouble was ahead for BME's financial development. Ever since, the council tried to advance the consolidation process by means of the measures at its disposal (Interview Reimann, 2008). However, when the council demanded in the late 1990s that the spa business be privatised or closed down, the city government did not follow suit.

Consequently, the supervisory authority appointed a state commissioner from 17 January 2000 to 31 August 2003, who took over all competencies of the municipal council and also some of the mayor's. Thus, the municipality was "administered from outside" for 3.5 years.

Among the state commissioner's tasks were not only closing down the spa business but also the management of the results thereof, the establishment of a stringent policy of savings and an overall improvement of the budgetary situation (Interview Bartos, 2007).

The privatisation of the spa business, the savings policy and the realisation of revenue potentials, as demanded by the supervisory authority and implemented by the state commissioner, did not suffice to achieve a sustainable consolidation of the town's budget. The town's lack of power to act, as determined by the supervisory authority before the state commissioner was appointed, could not be eliminated.

The employment of the state commissioner also underlined further problems. Processes of budget consolidations - especially in municipalities that are deeply in debt - are usually not short-term issues, and the implemetation of far-reaching projects takes several years. As state commissioners can hardly replace municipal bodies for years on end 
but are better-suited for temporary interventions, they can only have a limited effect on processes of budget consolidation. Their potential lies in that they do not shy away from unpopular measures that local policymakers do not dare to implement.

The commissioner's job is particularly difficult if at the time of his or her appointment, the municipal debt is already so high that even "hard" measures of consolidation could not bring about a sustainable improvement of the financial situation. Certainly, even minute improvements are preferable to no improvements at all; still, it seems almost impossible to balance the budget by mere means of a commissioner.

In this context, it should be noted that financial crises frequently develop in the form of "creeping catastrophes" (Böhret, 1993, p. 35). In some cases, the debt builds up very slowly. The scope of action is reduced only stealthily, which limits the pressure on political actors to act and also makes it hard or even impossible for them to estimate when the financial situation might capsise.

All this leads to the following hypothesis: As there are several legal and political obstacles to the appointment of a state commissioner, in combination with a number of other measures that precede it, and as it is hard to detect the "right" moment for his or her appointment, it may be that state commissioners are appointed systemically "too late". Thus, there are certain systemic limits to a state commissioner's effectiveness. It can therefore be assumed that in future cases, they will continue to play only a limited role in the genuine restoration of well-ordered budget management (Duve, 2008b).

\section{Preventive approaches to avoid budgetary hardships}

The problems of "repressive" measures like commissioners make plain the limited suitability of these instruments to cope with serious budgetary hardships. To prevent these to begin with, which seems to be the best solution than if they emerge accidentally rather than in a calculated way (which of course may also be the case), measures would be necessary that could strengthen the municipalities' and the Länder's realisation of and responsibility for problems afoot. 


\subsection{Systematic early diagnosis of municipal budgetary developments}

The main way of doing so is "early diagnosis". This is an instrument to make it possible to recognise symptoms of a looming crisis in time, to interpret them correctly and to react with appropriate measures (Uhlenbruck, 1998, p. 21). The municipality's situation becomes problematic especially if the indebtedness has gained so much momentum that it cannot be stopped within the municipality's realm of power. It is not all too easy for politicians to authoritatively identify that point, particularly as the situation of the economy - and also of the budget - can change very fast; a fact that can be witnessed at the moment.

There are only few Länder right now that pursue such a systematic prevention based on key figures, which has led to first - mostly positive experiences. Saxony is a maverick in this, as a key-figure-based system was established there as early as 2003, providing the Ministry of the Interior with information on the state of municipal budgets, including municipal special-purpose associations and housing corporations (Interview Dornig, 2008). This practice has also been adopted by Mecklenburg-Western Pomerania (Junker, 2007, p. 396); there are by now also similar systems in North Rhine-Westphalia and Thuringia (Interview Mnich, Hoffmann, 2008).

Both in Mecklenburg-Western Pomerania and in Saxony, the Ministry of the Interior's (the highest supervisory authority) sense of missing certain developments in the budgets of municipalities that belong to their administrative districts was an important reason for the establishment of these instruments. The supervisory authority was determined to beat the press to information about the budgetary problems of affected municipalities (Interview Dornig, 2008). This allows for the inference that it was not rare for the communication between various levels of municipal control to have been limited before, resulting in too late detections of budgetary imbalances.

Ever since the early diagnostic system was introduced, the budgetary situation of many municipalities has improved significantly in Saxony (Graph 1), reopening their scope of action. The decisive question is which concrete measures led to this, for the early diagnostic system as such does not yet change anything about the municipalities' financial situations. 


\section{Graph 1: Development of the budgetary situation of municipalities in Saxony's early diagnostic system}

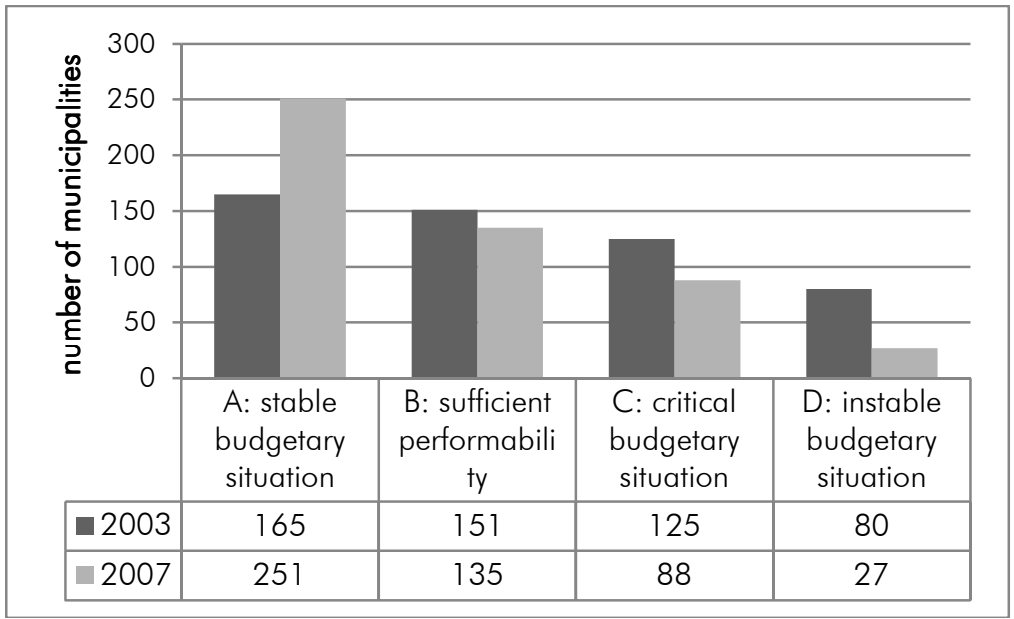

Source: Saxony Ministry of the Interior

Budgetary improvements were first and foremost reached by means of more intensive communication among the controlling levels (Interview Dornig, 2008). As regular budget discussions were implemented, attended by representatives of all levels of legal supervision, problematic cases could not only be identified but a modus operandi could also be determined, and concrete tasks could be assigned; thus, a more effective and more sustainable consolidation could be achieved. What apparently had been missing before was the control of lower levels of supervision by the top supervising body.

Mecklenburg-Western Pomerania published the results of the keyfigure system on the website of the Ministry of the Interior, a step that significantly increased the system's transparency. Each municipalitiy can follow where it is classified within the "Rubikon" (as the system is called) ${ }^{7}$ (Figure 1); furthermore, a number of key figures can be scrutinised that form the basis for the evaluation.

7 Rubikon stands for "Rechnerunterstütztes Haushaltsbewertungs- und Informationssystem der Kommunen" [Computer-supported system of evaluation and notification of municipal budgets]. It also plays on the Classic allusion to the river that to cross it signifies a nonreversible decision. 
Figure 1: Classification of municipalities and cities in the Rubikon in 2008

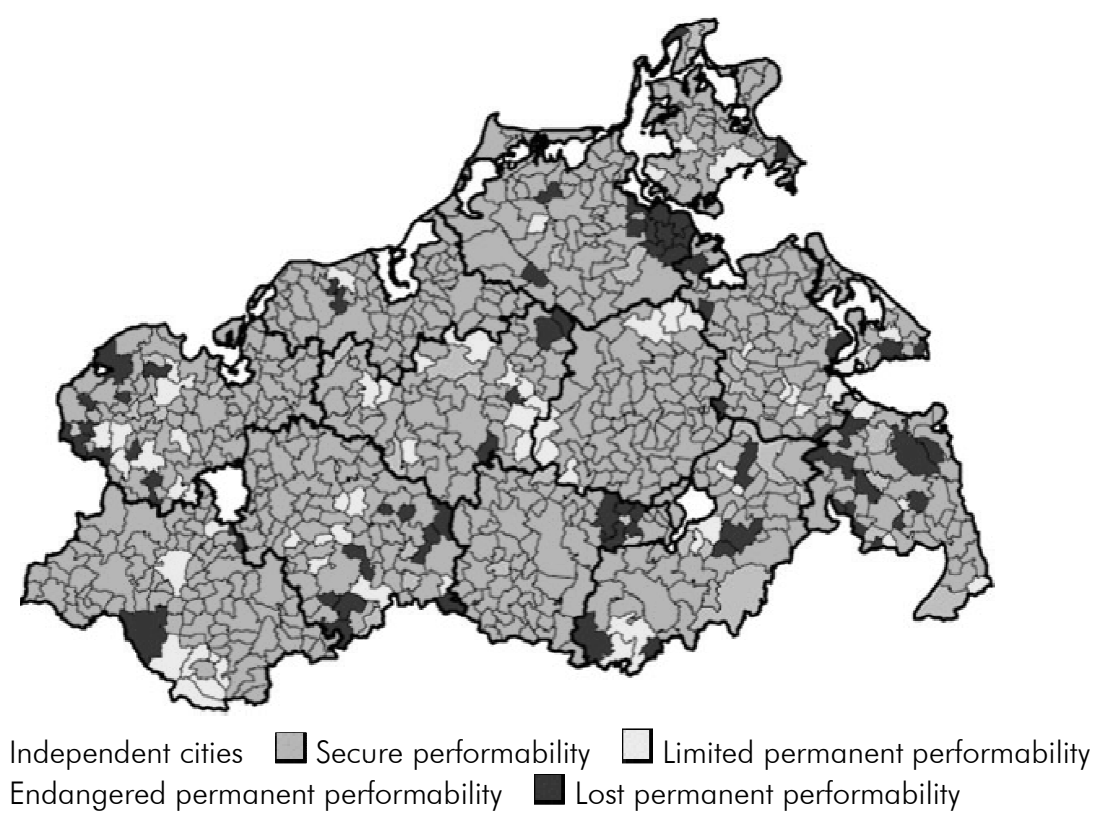

Source: http://www.im.mv-regierung.de/rubikon/kreisauswertung/index2007.html (Accessed on 15 September 2010)

This transparency resulted in an increasing level of public discussion regarding the financial situation of particular municipalities. This, in turn, also increased the pressure to act and/or succeed both on the municipal and Länder levels. According to the Ministry of the Interior, reactions have been consistently positive. The key figures have not been called into question in public discussion (Interview Hoerenz, 2008).

\subsection{Advisers and mentors as substitutes for commissioners}

The second less invasive option to prevent municipal insolvency is a modified version of the commissioner, which, as has been shown supra, brings with it a set of serious problems. For this reason, the supervisory authority in North Rhine-Westphalia opted in some cases to introduce a measure that interferes less with self-government, namely the appointment of external advisers, a position that so far has been tried in Waltrop (2006-2008), Marl (2007-2008) and Hagen (2008-2009). ${ }^{8}$ These external advisers, also referred to as "mentors" or "advisory savings

8 Regarding the specific cases, see www.sparkommissar-waltrop.de (Accessed on 15 September 2010); more city information under: www.marl.de; www.hagen.de; www.waltrop.de (Accessed on 15 September 2010). 
commissioners" by the press, were granted a comprehensive right of information. They did not, however, have the power to command; their task was to advise the municipalities regarding their budget consolidation, providing warnings and recommendations. The intention on the part of the supervisory authority is to give the municipalities the chance sto solve the budgetary problems to a substantial extent on their own. " 9 The municipalities' readiness to cooperate is regarded here as a necessary condition for the appointment of such an adviser. If they are not willing to do so, the municipal electorate may consider appointing a state commissioner ${ }^{10}$ to implement the measures that are required from the Länder's perspective.

The municipality still has the possibility to centrally shape the consolidation process according to its preferences. The external advisers' success is dependent on whether their warnings and recommendations are heeded and implemented. If the municipality fails to implement the measures, however, this might lead to a further delay of the whole process resulting in an ever graver crisis. As the readiness to cooperate is more or less forced upon the municipalities, this measure remains a balancing act between a paternalism of sorts and self-government.

Much depends on the local context, the concrete sources of the debts, the size of the municipality and also the time when the adviser is appointed. If he or she finds that all possible measures for budget consolidation have already been exhausted without sustainable improvements, a state commissioner will not be able to ameliorate the financial situation either. In these cases, the adviser is not a stage before the state commissioner but the final stage. The situation is different if there are still exhaustable measures that are not implemented because the municipality does not properly follow the adviser's recommendations. As external advisers do not have the power to direct, these cases call for the appointment of a state commissioner to implement the necessary measures.

9 Justification of Münster's district government regarding the appointment of an external adviser in the city of Waltrop according to $\S 124$ GO NRW analog, from 11 January 2006, 10.

10 Reply by the Ministry of the Interior from 23 January 2007 to inquiry 1266 from 20 December 2006, Landtag NRW, Drucksache 14/3617. 
As regards the three specific cities, in Marl and Waltrop, approvable concepts for budget stability were drawn up, which had been deemed unthinkable by the supervisory authority before the appointment of the advisers. Time will tell if their appointment actually brings about the desired success in the end; this also depends on whether the cities remain consistent in pursuing a sustainable consolidation strategy. In February 2009, a commission was created in Hagen, consisting of the city's political leadership and the supervisory authority, to work out a concept for a balanced budget. The former external adviser's recommendations served as a basis for this (Jakobs, 2009, p. 3).

Still, the "adviser approach" can only be regarded as a preventive measure to a limited degree. His or her appointment is intended to avoid the involvement of a state commissioner, it is true. However, when an adviser is used in a commissioner's stead, the crisis must have reached an advanced stage. Thus, systemically, advisers are appointed in order to rid the municipalities of crises that exist already. On account of the advanced debt dynamic, this can lead to problems similar to those connected to commissioners.

\section{Conclusion}

In an international context, German approaches to preventing municipal insolvency can be summed up as follows:

1. Normatively, while preventing municipal insolvency is important, it may not serve as an excuse to abrogate local independence, and care must be taken to steer a middle course.

2. This is especially the issue with state-appointed commissioners: If they are sent too early in the process, they violate local independence; if too late, they can no longer be effective.

3. Thus, it is more sensible to focus on prevention, which is best done through the development of (mandatory) indicators that reflect imminent problems of the municipal budget. In cases where the reason for a coming insolvency is less ill will than lack of knowledge, this is indeed the most promising approach.

Is any trans-national lesson-drawing from Germany possible and/or desirable in this case? Of course, the complexities of a possible transfer are as immense as is the general issue of policy-learning and the issue of best practices (Randma-Liiv, 2007). In addition, radical discontinuities in 
the nature of the current crisis (though it was by no means impossible to foresee, including the effects on the public sector; see Drechsler, 2009b) make extrapolations from previous experiences difficult. Nonetheless, within the discussion of how to best prevent local insolvency, it should be interesting to note, especially during times of crisis, that the German experience shows that cooperation between the local level and the coordinating and supervising level "above" is much more promising and effective than any hard-handed intervention that may easily lead to the diminishing of municipal autonomy, which in the end would be detrimental to the interests of the state as such and of all of its citizens.

Thomas Duve is consultant and project manager at the Working Group for Efficient Administration - registered association, Eschborn, Germany. He is responsible for topics dealing with PA Reform and Deregulation. Furthermore, he is associate lecturer at the German University of Administrative Sciences Speyer (DHV) and has worked as a Research and Teaching Assistant at the Chair of Public Administration and Public Law at the DHV Speyer.

Wolfgang Drechsler is Professor and Chair of Governance at Tallinn University of Technology, Estonia, co-director of its graduate Technology Governance program and Vice Dean for International Relations for its Faculty of Social Sciences. He has served as Advisor to the President of Estonia, as Executive Secretary with the German Wissenschaftsrat during the German Reunification and as a Senior Legislative Analyst in the United States Congress (as APSA Congressional Fellow). 


\section{References}

- Albers, H. (2006). Haftung für kommunale Verbindlichkeiten. Landkreis, 76, 750-756.

- Albers, H. (2005). Von der Konkursunfähigkeit zur Zahlungsunfähigkeit: Aktuelle Probleme der kommunalen Haushalte. Niedersächsische Verwaltungsblätter, 3, 57-66.

- Blankart, C. (2007). Aussage als Sachverständiger in der öffentlichen Anhörung zur Föderalismusreform Il am 22. Juni 2007. Kommissionsdrucksache 22.

- Blankart, C., Fasten, E. \& Klaiber, A. (2006). Föderalismus ohne Insolvenz. Wirtschaftsdienst, 86, 567-571.

- Bock, O., Hein, R. \& Weinberger, A. (2010). So gut wie insolvent, FAZ.net, 10 August. Available at: http://www.faz.net/s/Rub8D051 17 E1AC946F5BB438374CCC294CC/Doc $\sim$ E9FFF1EED91084C66BF1 CD85DE5AAB829 ATpl Ecommon Scontent .html (accessed 13 March 2011 ).

- Böhret, C. (1993). Funktionaler Staat. Frankfurt: Lang.

- Borchert, H. (2004). Beschränkte Insolvenzfähigkeit für Kommunen. Gemeinde SH, 1, 2-3.

- Bundesministerium der Finanzen (BMF) (2010). Kabinett beschließt Einrichtung einer Gemeindefinanzkommission. Available at: http://www.bundesfinanzministerium.de/nn_4320/DE/Presse/Pressemitteilun gen/Finanzpolitik/2010/02/20102402_PM07.html?_nnn=true (accessed 13 March 2011)

- Bundesministerium der Finanzen (BMF) (2009). Die Wirtschafts- und Finanzkrise: Konjunktur- und strukturpolitische Antworten ausgewählter Volkswirtschaften. Monatsbericht August 2009. Available at:

http://www.bundesfinanzministerium.de/nn_84204/DE/BMF_Startseite/Akt velles/Monatsbericht_des_BMF/2009/08/analysen-und-berichte/b06finanzkrise-antworten/finanzkrise-antworten.html\#initiiert (accessed 13 March 2011).

- Burgi, M. (2006). Kommunalrecht. München: Beck.

- Drechsler, H. (2001). Kommunalpolitik. In: Drechsler, H., Hilligen, W. \& Neumann, F. (Eds.). Gesellschaft und Staat. Lexikon der Politik, 10th Edition. München: Vahlen.

- Drechsler, W. (2009a). NanoGov - Nanotechnologie, Innovation, Governance und Verwaltung aus der Perspektive der Techno-Ökonomischen Paradigmen. In: Scherzberg, A. \& Wendorff, J. (Eds.). Nanotechnologie - 
Grundlagen, Anwendungen, Risiken, Regulierung, 307-325. Berlin: de Gruyter Recht.

- Drechsler, W. (2009b). Governance in and of Techno-Economic Paradigm Shifts: Considerations for and from the Nanotechnology Surge. In:

Drechsler, W., Kattel, R. \& Reinert, E. (Eds.). Techno-Economic Paradigms: Essays in Honour of Carlota Perez, 95-104. London and New York: Anthem.

- Drechsler, W. (2009c). The Rise and Demise of the New Public Management: Lessons and Opportunities for South East Europe. UpravaAdministration 7(3), 7-27.

- Drechsler, W. (2008). Foundations of Municipal Autonomy: Karl Freiherr vom Stein at 250 and the Preußische Städteordnung at 200. NISPAcee Journal of Public Administration and Policy, 1 (1), 137-141.

- Drechsler, W. (2007). Safeguarding Municipal Autonomy by the Supreme Court. Juridica International, (13), 111-115.

- Drechsler, W. (1999). Kommunale Selbstverwaltung und Gemeindegebietsreform: Deutsche Erfahrungen, prinzipielle Erwägungen, estnische Perspektiven. In: Drechsler, W. (Ed.). Die selbstverwaltete Gemeinde: Beiträge zu ihrer Vergangenheit, Gegenwart und Zukunft in Estland, Deutschland und Europa, 97-110. Berlin: Duncker und Humblot.

- Duchhardt, H. (2007). Stein: Eine Biographie. Münster: Aschendorff.

- Duve, T. (2009a). Die Verschuldung deutscher Gemeinden: Präventionsansätze im Spannungsverhältnis von kommunaler Selbstverwaltung und staatlicher Gesamtverantwortung. Ph. D., Tallinn University of Technology.

- Duve, T. (2009b). Die Wiederentdeckung der kommunalen Insolvenz im Kontext bestehender Präventions- und Sanierungsstrategien. Öffentliche Verwaltung 62(14), 574-580.

- Duve, T. (2008a). Haushaltsnotlagen bei Kommunen: Kommunale Besonderheiten, Indikatoren und Selbstverantwortung. Öffentliche Verwaltung 61 (1), 22-27.

- Duve, T. (2008b). Staatskommissare als Manager kommunaler Haushaltskonsolidierungsprozesse. Verwaltung und Management 14(6), 283-293.

- Engelsing, F. (1999). Zahlungsunfähigkeit von Kommunen und anderen juristischen Personen des öffentlichen Rechts: Vollstreckung und finanzielle Einstandspflicht. Stuttgart et al.: Boorberg.

- Etzemüller, T. (Ed.) (2009). Die Ordnung der Moderne: Social Engineering im 20. Jahrhundert. Bielefeld: Transcript. 
- Faber, A. (2005). Insolvenzfähigkeit von Kommunen. Deutsche Verwaltungsblätter 120(15), 933-946.

- Falk, M. (2006). Die kommunalen Aufgaben unter dem Grundgesetz. Kommunalrecht: Kommunalverwaltung 50. Baden-Baden: Nomos.

- Forsthoff, E. (1958). Die Daseinsvorsorge und die Kommunen. KölnMarienburg: Sigillum.

- Frielinghaus, S. (2008). Das Tabu der kommunalen Insolvenz. Öffentliche Verwaltung, 61, 991-997.

- $\quad$ Frischmuth, B. (2008). Neves kommunales Finanzwesen: Von der Kameralistik zur Doppik. In: Lorig, W. (Ed.). Moderne Verwaltung in der Bürgergesellschaft: Entwicklungslinien der Verwaltungsmodernisierung in Deutschland, 136-143. Baden-Baden: Nomos.

- Gern, A. (2003). Deutsches Kommunalrecht. 3rd Edition. Baden-Baden: Nomos.

- Henneke, H.-G. (2008a). Die kommunale Position bei der Neuordnung der Finanzbeziehungen im deutschen Bundesstaat. In: Baus, R., Eppler, A. \& Wintermann, O. (Eds.). Zur Reform der föderalen Finanzverfassung in Deutschland: Perspektiven für die Föderalismusreform // im Spiegel internationaler Erfahrungen, 229-234. Baden-Baden: Nomos.

- Henneke, H.-G. (2008b). Begrenzt die Leistungsfähigkeit des Landes den Finanzausstattungsanspruch der Kommunen? Öffentliche Verwaltung, 61 , 857-867.

- Isin, E. (2002). Being Political: Genealogies of Citizenship. Minneapolis: University of Minnesota Press.

- IWD-Institut der deutschen Wirtschaft (2010). Insolvenzrecht gesucht. Iwd, 32,6 .

- Jakobs, N. (2009). Das Ende der Finanzillusion. Neve Kämmerer, 1 February, 3.

- Junker, M. (2007). Kennzahlengestützte Bestimmung der dauernden Leistungsfähigkeit von Kommunen in Mecklenburg-Vorpommern: "RUBIKON" als Beitrag zur Haushaltskonsolidierung. Landes- und Kommunalverwaltung, 17, 396-401.

- Junkernheinrich, M. (2007). Ist es möglich, die Aufgabenangemessenheit der kommunalen Finanzausstattung zu bestimmen?: Finanzwissenschaftliche Überlegungen zur intraföderalen Finanzaufteilung. In: Junkernheinrich, M., Scheller, H. \& Woisin, M. (Eds.). Zwischen Reformidee und Funktionsanspruch: Konzepte und Positionen zur deutschen Finanzverfassung, 173-192. Berlin: Analytica. 
- Junkernheinrich, M. \& Micosatt, G. (2008). Kommunaler Finanz- und Schuldenreport Deutschland. Gütersloh: Bertelsmann.

- Käppner, J. (2009). Kommunale Krise. Süddeutsche Zeitung, 27 April, available at: http://www.sueddeutsche.de/wirtschaft/831/466413/text/ (accessed 1 December 2010).

- Kirbach, R. (2009). Für dumm verkauft. Zeit, 3 March, available at: http://www.zeit.de/2009/12/DOS-Cross-Border-Leasing (accessed 13 March 2011).

- Klein, O. (2005). Fehlentwicklungen im Gemeindefinanzsystem. In: Nierhaus, M. (Ed.). Kommunalfinanzen: Beiträge zur aktuellen Debatte. KWIArbeitsheft 9, 69-84. Potsdam: Potsdam University Press.

- Knemeyer, F.-L. (1997). Verfassung der kommunalen Selbstverwaltung. In: König, K. \& Siedentopf, H. (Eds.). Öffentliche Verwaltung in Deutschland, 2nd Edition, 203-215. Baden-Baden: Nomos.

- Lenk, T. \& Rudolph, H.-J. (2005). Die kommunalen Finanzausgleichssysteme in der Bundesrepublik Deutschland. In: Nierhaus, M. (Ed.). Kommunalfinanzen: Beiträge zur aktuellen Debatte, KWI-Arbeitsheft 9, 5768. Potsdam: Potsdam University Press.

- Meyer, H. (2007). Aussage als Sachverständiger in der öffentlichen Anhörung zur Föderalismusreform I/ am 22. Juni 2007. Kommissionsdrucksache 14.

- Oberhessische Presse (2010). Kommunen sollen sparen. 21 October.

- OECD (2010). Economic Surveys Germany 2010. OECD.

- Paulus, C. (2003). Überlegungen zur Insolvenzfähigkeit von Gemeinden. Zeitschrift für das gesamte Insolvenzrecht, 6, 869-872.

- Peters, B.G., Pierre, J. \& Randma-Liiv, T. (2010). Economic Crisis, Public Administration and Governance. Unpublished manuscript.

- Pollitt, C. et al. (Eds.). (2009). A Distinctive European Model? The NeoWeberian State. The NISPAcee Journal of Public Administration and Policy, 1 (2).

- Randma-Liiv, T. (2007). From Policy Transfer to Policy Learning in Central and Eastern Europe. In: Coombes, D. \& Vass, L. (Eds.). Post-Communist Public Administration: Restoring Professionalism and Accountability, 27-36. Bratislava: NISPAcee Press.

- Raske, W. (1971). Die kommunalen Investitionen in der Bundesrepublik: Struktur, Entwicklung, Bedeutung. Stuttgart et al.: Kohlhammer.

- Reichwein, A. (2007). 10 Jahre NSM: Bilanz der Umsetzung des Neuen Steverungsmodells. Presentation at the conference 
Verwaltungsmodernisierung: Enfahrungen und Perspektiven at the Deutsche Hochschule für Verwaltungswissenschaften (DHV), Speyer, 17 October.

- Ritter, G. (1981). Stein: Eine politische Biographie, 4th Edition. Stuttgart: Deutsche Verlags-Anstalt.

- Schmidt-Aßmann, E. (1991). Kommunale Selbstverwaltung "nach Rastede": Funktion und Dogmatik des Art. 28 Abs. 2 GG in der neveren Rechtsprechung. In: Franßen, E. et al. (Eds.). Bürger - Recht - Staat, FS for Horst Sendler, 121-138, München: Beck.

- Schwarting, G. (2008). Haushaltskonsolidierung: ein aktuelles Thema? Zeitschrift für Kommunalfinanzen, 58, 265-271.

- Schwarting, G. (2005). Einige Gedanken zur fiskalischen Disziplin kommunaler Gebietskörperschaften in Deutschland. In: Genser, B. (Ed.). Haushaltspolitik und öffentliche Verschuldung, 131-169. Berlin: Duncker und Humblot.

- Seitz, H. (2008). Fiskalische und ökonomische Aspekte der Verwaltungsreform in Schleswig-Holstein. In: Landesregierung SchleswigHolstein (Ed.). Gutachten zur Verwaltungsstruktur- und Funktionalreform in Schleswig-Holstein, 583-764. Kiel: Lorenz-von-Stein-Inst. für Verwaltungswiss. an der Christian-Albrechts-University.

- Statistisches Bundesamt (2010a). Große Finanzlücke bei den kommunalen Haushalten 2009. Press Release 1 14, 23 March, available at: http://www.destatis.de/jetspeed/portal/cms/Sites/destatis/Internet/DE/Presse /pm/2010/03/PD10_114_71137,templateld =renderPrint.psml (accessed 13 March 2011).

- Statistisches Bundesamt (2010b). Statistisches Jahrbuch 2010. Wiesbaden: Statistisches Bundesamt.

- Stern, F. (1996). Europäische Union und kommunale Selbstverwaltung. In: Nierhaus, M. (Ed.). Kommunale Selbstverwaltung: Europäische und nationale Aspekte, 21-44. Berlin: Duncker und Humblot.

- Uhlenbruck, W. (1998). Neves Insolvenzrecht: Wege aus dem modernen Schuldenturm. Bonn: DIHT.

- Wagener, F. \& Blümel, W. (1997). Staatsaufbau und Verwaltungsterritorien. In: König, K. and Siedentopf, H. (Eds.). Öffentliche Verwaltung in Deutschland, 2nd Edition, 109-122. Baden-Baden: Nomos.

- Die Welt (2010). Gemeinden fürchten 2010 Rekorddefizit, 24 March.

- Werner-Jensen, A. (2006). Planungshoheit und kommunale Selbstverwaltung. Baden-Baden: Nomos. 
- Bartos, Harald, Former State Commissioner in Bad Münster am SteinEbernburg (October 2007).

- Bergmann, Sebastian, Department Head, Local Government/Public-Private Partnerships/Institutions, Deutscher Sparkassen- und Giroverband e.V. (German Savings Banks Association) (November 2008).

- Dedy, Helmut, Deputy Executive Director, Deutscher Gemeinde- und Städtebunde (German Association of Municipalities) (November 2008).

- Dornig, Uta, Ministry of the Interior of the Free State of Saxony (October 2008).

- Frischmuth, Birgit, Executive Secretary within the Finance Department, Deutscher Städtetag (German Cities Association) (November 2008).

- Hoerenz, Michael, Ministry of the Interior of Mecklenburg-Western Pomerania (October 2008).

- Hoffmann, Landesverwaltungsamt Thuringia (October 2008).

- Kirchmer, Manfred, Ministry of the Interior of Saxony-Anhalt. (October 2008).

- Mnich, Stefan, Ministry of the Interior of North Rhine-Westphalia (October 2008).

- Penzenstadler-Hennig, Larissa, Ministry of the Interior of Brandenburg (October 2008).

- Puhr, Klaus, Ministry of the Interior of the Free State of Bavaria (October 2008).

- Reimann, Walter, Municipal Supervisory Authority Bad Kreuznach (June 2008).

- Schoon, Hermann, Former Mayor, Bad Münster am Stein-Ebernburg (September 2007).

- Stöfen, Klaus, Ministry of the Interior of Schleswig-Holstein (October 2008).

- Wagenführer, Andreas, Ministry of the Interior Rhineland-Palatinate (October 2008).

- Wohltmann, Matthias, Department I: Public Finances, Deutscher Landkreistag (German Counties Association) (November 2008).

- Würger, Silke, Ministry of the Interior of Mecklenburg-Western Pomerania (October 2008).

32 Uprava, letnik IX, 2/2011 


\section{Legal sources}

- Antwort des Innenministeriums vom 23. Januar 2007 auf die kleine Anfrage 1266 vom 20. Dezember 2006, Landtag NRW, Landtagsdrucksache $14 / 3617$.

- Gemeindeordnung des Landes Baden-Württemberg in der Fassung vom 24. Juli 2000 (GBI. S. 582), zuletzt geändert durch Gesetz vom 14. Oktober 2008 (GBI. S. 343).

- Gemeindeordnung (GemO) des Landes Rheinland-Pfalz in der Fassung vom 31. Januar 1994 (GVBI. 1994, S. 153), zuletzt geändert am 19. März 2009, (GVBI. S. 104).

- Gemeindeordnung für das Land Nordrhein-Westfalen (GO NRW) in der Fassung der Bekanntmachung vom 14. Juli 1994.

- Gemeindeordnung für das Land Sachsen-Anhalt (GO LSA) vom 5. Oktober 1993 (GVBI. LSA S. 568), zuletzt geändert durch Gesetz vom 22. Dezember 2004 (GVBI. S. 856).

- Gemeindeordnung für den Freistaat Bayern in der Fassung der Bekanntmachung vom 22. August 1998 (GVBI. 1998, S. 796), zuletzt geändert durch Gesetz vom 20. Dezember 2007 (GVBI. S. 958).

- Gemeindeordnung für den Freistaat Sachens (SächsGemO) in der Neufassung der Bekanntgabe vom 18. März 2003 (SächsGVBI. 2003 BI.Nr. 4 S. 55), Rechtsbereinigt mit Stand vom 11. Juni 2005.

- Gemeindeordnung für Schleswig-Holstein (GO) in der Fassung vom 28. Februar 2003 (GVOBI. 2003, S. 57), zuletzt geändert durch Gesetz vom 30. Juni 2008, GVOBI. S. 310)

- Gesetz zur Umsetzung von Zukunftsinvestitionen der Kommunen und der Länder (Zukunftsinvestitionsgesetz - ZulnvG) vom 2. März 2009, BGBI. 2009 I, S. 416,428 )

- Grundgesetz der Bundesrepublik Deutschland, Stand Januar 2007.

- Hessische Gemeindeordnung (HGO) in der Fassung vom 1. April 2005 (GVBI. I S. 142).

- Kommunalselbstverwaltungsgesetz (KSVG) des Saarlands in der Fassung der Bekanntmachung vom 27. Juni 1997 (Amtsbl. S. 682), zuletz† geändert durch Gesetz vom 29. August 2007 (Amtsbl. S. 1766).

- Kommunalverfassung des Landes Brandenburg (BbgKVerf) vom 18. Dezember 2007 (GVBI. I/07 S. 286).

- Kommunalverfassung für das Land Mecklenburg-Vorpommern (KV M-V) in der Fassung der Bekanntmachung vom 8. Juni 2004 (GVOBI. M-V 2004, S. 205). 
Thomas Duve, Wolfgang Drechsler

Insolvent Local Government:

German Approaches to Prevention

- Niedersächsische Gemeindeordnung (NGO) in der Fassung vom 28. Oktober 2006 (Nds. GVBI. 2006, S. 473).

- Ordnung für sämmtliche Städte der Preußischen Monarchie mit dazu gehöriger Instruktion, Behuf der Geschäftsführung der Stadtverordneten bei ihren ordnungsmäßigen Versammlungen. Vom 19ten November 1808, Introduction; new text edn. as Die Preußische Städteordnung von 1808, Stuttgart/Köln 1957.

- Solvabilitätsverordnung - Verordnung über die angemessene Eigenmittelausstattung von Instituten, Institutsgruppen und FinanzholdingGruppen (SolvV), in der Fassung der Bekanntmachung vom: 14. Dezember 2006 (BGBI. I, S. 2926)

- Thüringer Gemeinde- und Landkreisordnung (Thüringer Kommunalordnung - ThürKO) in der Fassung der Bekanntmachung vom 28. Januar 2003 (GVBI. 2003, S. 41).

- Verfassung für Rheinland-Pfalz vom 18. Mai 1947 (VOBI. 1947, S. 209) zuletzł geändert durch Gesetz vom 16. Dezember 2005 (GVBI. 2005, S. 495).

- Verordnung über die angemessene Eigenmittelausstattung von Instituten, Institutsgruppen und Finanzholding-Gruppen (Solvatibilitätsverordnung), BGBI. 2006 I, S. 2926. 
POVZETEK

\section{NEMŠKI PRISTOP K PREPREČEVANJU PLAČILNE NESPOSOBNOSTI LOKALNIH UPRAV}

Ključne besede: lokalna samouprava, lokalne finance, finančna kriza, plačilna nesposobnost občine, preventiva

Svetovna finančna kriza še zlasti močno napada lokalne uprave, kar še posebej velja za države Srednje in Vzhodne Evrope. Mnogim lokalnim upravam grozi velika nevarnost plačilne nesposobnosti, zato je žal prav zdaj zares pravi trenutek za to, da si pogledamo to vprašanje. Ali lahko nekdo sploh dejansko bankrotira? Ali bi morali dovoliti, da to tega pride? Ali je bankroł mogoče preprečiti, in če ga ni, kako ga ustrezno obvladati?

S tem esejem želiva empirično raziskati, kako se je Nemčija do tega trenutka, torej pred zlomom, lotevala vprašanja plačilne nesposobnosti občin. Pristop, ki so mu sledili pred krizo, samo še podkrepi dejstvo, za kako pomembno tematiko gre, saj kaže, da so bile občine izpostavljene hudim finančnim pritiskom tudi že $v$ bolj ali manj finančno trdnih obdobjih. Med krizo pa se je število občin, ki se soočajo s proračunsko krizo, še povečalo. Rezultati te raziskave bodo lahko $v$ pomoč pri soočanju s posledicami krize. Zaradi visoke avtonomije občin, ki je dejansko postala paradigma, bi morala biti še zlasti za države Srednje in Vzhodne Evrope zanimiva možnost pridobivanja spoznanj iz Nemčije.

Nemške zvezne države lahko v izogib proračunski krizi in torej hudo kritičnemu stanju življenja občine ravnajo na več načinov. S svojimi ukrepi lahko posegajo $v$ lokalno samoupravo, zato je treba cilje in učinke ukrepov previdno uskladiti med seboj.

Ta esej se osredotoča na troje: na obravnavo pojma "proračunska kriza", na njegovo uporabnost na ravni občin in stopnjo odgovornosti nemških zveznih držav za proračunsko krizo na občinski ravni, na empirično raziskavo rabe državnih nadzornikov $v$ kontekstu konsolidacije proračuna, razpravo o rabi zunanjih svetovalcev pri teh procesih in razpravo o pristopu $k$ bankrotu občin, pa tudi na pregled in oceno sedanjih preventivnih pristopov nemških zveznih držav.

Nemške lekcije za plačilno nesposobne občine lahko okvirno povzamemo na naslednii način (vedno v nemškem kontekstu): 
Thomas Duve, Wolfgang Drechsler

Insolvent Local Government:

German Approaches to Prevention

Pomembno je sicer preprečiti plačilno nesposobnost občin, vendar to ne sme biti izgovor za odpravo neodvisnosti lokalnih skupnosti. Treba je ubrati srednjo pot.

To še zlasti velja za vprašanje nadzornikov, ki jih imenuje država: če jih pošlje prezgodaj, kršijo neodvisnost lokalnih skupnosti; če pa prepozno, ne morejo več učinkovito delati.

Zato je pametneje usmeriti pozornost na preventivo, najbolje z oblikovanjem (zavezujočih) kazalnikov, $v$ katerih se zrcalijo skorajšnje težave $v$ občinskem proračunu. Ta pristop zagotovo največ obeta $v$ primerih, ko je plačilna nesposobnost boli posledica nezadostnega znanja kot pa zlonamernega ravnanja. 